\title{
The Effect of Commercial Advertising on Customer Orientation in the Banking System
}

\section{(Case Study: The Branches of Mellat Bank in Guilan Province- North of Iran)}

\author{
Seyed Javad Mousavian ${ }^{1 *}$, Mohammad Taleghani \\ 1Department of Business Management, Central Tehran Branch, Islamic Azad University, Tehran, Iran \\ 2Department of Industrial Management, Rasht Branch, Islamic Azad University, Rasht, Iran
}

*Corresponding Author: Seyed Javad Mousavian, Department of Business Management, Central Tehran Branch, Islamic Azad University, Tehran, Iran

\begin{abstract}
Nowadays, concerning the competitive atmosphere which governs the banks regarding e-services, using advertisement to introduce services has a significant role in inspiring and motivating customers in using products and services and consequently attracting them to use their e-services. In other words, if the banks wish to evaluate the efficiency of their advertisement on the customers, they can perform better in future which is a distinctive competence for the banks. In this regard, there have been various researches throughout the country which merely investigated the effective factors in advertising or the advertising facilities. The present study was conducted on the customers of the branches of Mellat Bank in Guilan province, aiming to answer whether advertisement has caused any improve in the customers' attraction to use the branches of Mellat Bank e-services, such as mobile banking, telephone banking, internet banking, shopping centers' POS (Point of Sale), and ATM (Automated Teller Machine), and if they are effective, the effect of which ones (television advertisement, radio advertisement, catalogues and brochures, press or oral advertising) are more considerable. The present research is an applied research which has gathered the questionnaires regarding the feedbacks of the customers of the branches of Mellat Bank in Guilan province using library sources, bank data and the viewpoints of the related experts. The SPSS and regression were used to analyze the options of the questionnaires and to determine the effects of advertising elements and communication media and ultimately the effect of advertising on the attraction of the customers to the ebanking services. Moreover, the communication media was investigated and the most influential method of advertising was introduced. Finally, while the research hypotheses were investigated, this study concludes with suggestions for further research.
\end{abstract}

Keywords: Commercial Advertising, Customer Orientation, Electronic Services.

\section{INTRODUCTION}

Nowadays on the one hand organizations are trying to introduce their goods and services and announced distinguishes it from similar products using various advertising media because send influential messages in order to persuade customers to buy. On the other hand, people are surrounded with a variety of advertising through various media at any time and any place and in fact evaluating effectiveness of advertising is important (Rabiei \& Mohammadia, 2019: 17-40).

Physical distance of bank branch and client, distance of client and financial adviser and the resulting uncertainty on overall environment of internet creates special challenge in electronic banking and internet because banks find ways which start and continue electronic commerce relationships effectively (Claudia, 2011). Reliability and customer satisfaction is an important challenge in ebanking that bank managers faced with it and other research is needed (Ademola, 2019).

\section{Statement of Problem}

In Iran, due to the increasing number of banks and offering similar services, banks have faced with a big problem to attract customers and as a result their deposits. Therefore banks in this competitive environment to maintain market share or increase its share of market should have a suitable plan for delivering advertising. Unfortunately, Iran has not paid much attention to assess the effectiveness of 
advertising that reason can be cited the novelty of the advertising industry, lack of adequate information and a lack of familiarity with the patterns and models for evaluating the effectiveness of advertising managers and a lack of practical examples in this field (Rabiei \& Mohammadian, 2019).

Changes in the type of client's transaction in bank from physical presence of customers in branches and doing transaction with bank to use of postal services to transport and deposit money and perform other banking operations, the transaction via phone and contact center with customers, use keys of phone to interact with bank and accountability audio and video, do banking via PC, using a modem and special software and finally use of internet reflects historical path of changes that is lead to improve and increase the diversity of banking services to customers (Gilaninia \& et al, 2018a). The emphasis on continuous change and structural alignment with environmental changes, strategy and technology of banks, supporting creativity and innovation in banking services, continuous improvement of service quality and attitude change in management and human resources in the field of value creation for customers has always been consider the world's top banks. Internationally successful banking experience has shown that bank to maintain and improve its position in existing markets by creating new markets required providing new services and at the same time improving its existing services. To achieve this goal, bank take advantage different strategies including diversification strategy and the strategy of improving service (Rasool F-Jalal, 2018: 6).

Banks can also use communication methods to introduce their products and services. Communication objectives include raising awareness, persuade and remind to current customers and potential customers about the product or company (Gilaninia \& et al, 2018b). When a new product is introduced to the market and the aim is to create initial demand, awareness advertising is very used. When competition increases and the aim are creating selective demand, persuasive advertising is used. When the product be in the curve of their life in their mature stage and the aim is that the consumer think about the product constantly, reminder advertising is used (Rezaei \& Mohammad, 2019). Advertising is caused a change in attitudes, knowledge and behavior of the audience. Awareness, persuasion, encouragement, reminders, strengthening relations and accelerating and promote exchanges including various tasks of advertising that by examining effects of advertising and its relationship with organizational goals can done changes in the advertising budget to content of messages and media type and communication channels and even time and conditions of advertising because advertising is done more useful and effective than in the past (Parhizgar \& Mehdipour, 2020:3).But important issue is that banks given the intense competition structure prevailing them in the supply of electronic services have turned to the media extensive advertising to introduce its services. Since effects of different advertising on different people is different and what effect have on their awareness, encourage to use the products and services and ultimately attract them to use ebanking services, thus it is necessary for banks. In other words, if banks can evaluate the effectiveness of their advertising on customers, thus have a better performance in the future. This can be considered as a competitive advantage for banks. In this research, advertising is considered as independent variable and attracting customers to use electronic services of bank as dependent variable.

Thus, according to statement contained, proposed analytical model of study is as follows:
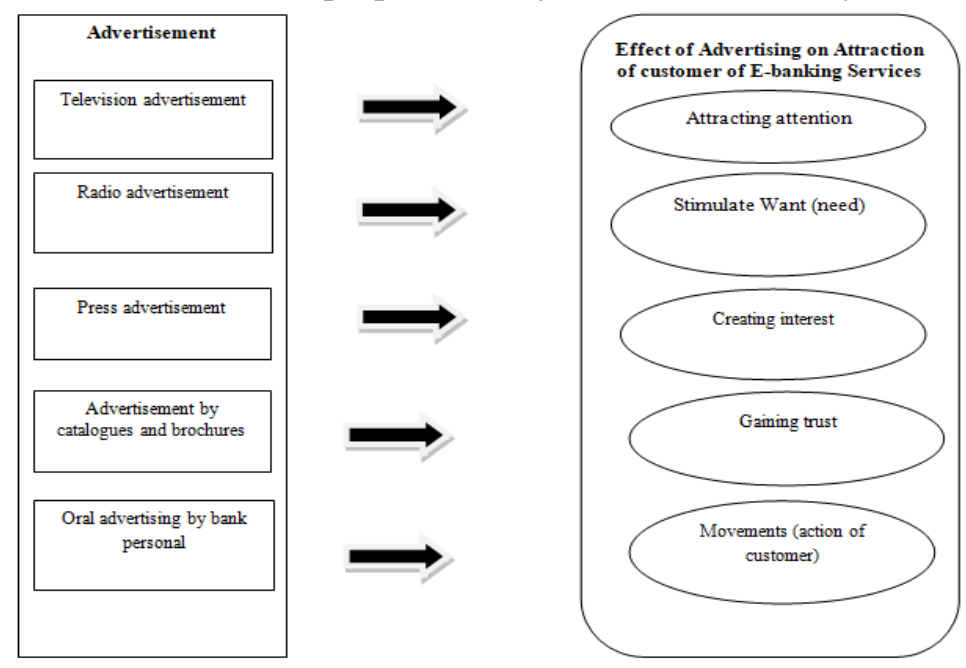

Figure1. Research- made model (effect of advertising on increase attracting customers of electronic banking services) 
It should be noted that the box advertising is advertising methods and it is used as independent and main variables of research hypothesis in this study and elements increase attracting customers of electronic banking services is elements that each of independent variables of study through it (attracting customers of electronic banking services) affect dependent variable.

\section{RESEARCH HYPOTHESES}

\subsection{Main Research Hypothesis}

Advertising increases attracting customers to use electronic services.

\subsection{Sub-Hypotheses}

1. Television advertisement increases attracting customers to use electronic services.

2. Radio advertisement increases attracting customers to use electronic services.

3. Press advertisement increases attracting customers to use electronic services.

4. Advertisement by catalogues and brochures increases attracting customers to use electronic services.

5. Oral advertising by bank personal and customer increases attracting customers to use electronic services.

\section{RESEARCH METHODOLOGY}

This study in terms of purpose is considered applied and its method is descriptive-survey, in terms of data collection is field research. Statistical population of this research is customers of electronic services in Mellat bank branches Guilan province- North of Iran. Suitable sample size for distribution is calculated 384, thus 384 questionnaires is distributed. It should be noted, sampling method in this study is random sampling. Cronbach's alpha method is used to test the reliability of the questionnaire. Given that Cronbach's alpha coefficient was obtained more than $70 \%$ so questionnaire has been reliable. In this study, SPSS software: v18 and Regression test used to analyze the hypotheses.

\section{RESEARCH FINDINGS}

\subsection{First Sub-Hypothesis}

Television advertisement increases attracting customers to use electronic services.

$\mathrm{H}_{0}$ : Television advertisement doesn't increase attracting customers to use electronic services.

$\mathrm{H}_{1}$ : Television advertisement increases attracting customers to use electronic services.

Table1. Correlation coefficient between Television advertisement and increase attracting customers

\begin{tabular}{|r|r|r|r|r|}
\hline Variables & Number & Correlation coefficient & Sig & Result \\
\hline $\begin{array}{l}\text { Television advertisement and } \\
\text { increase attracting customers }\end{array}$ & 384 & 0.14 & 0.003 & Confirmed \\
\hline
\end{tabular}

According to the table can be seen that sig $=0.000<0.05$, for this reason with $95 \%$ confidence $\mathrm{H}_{0}$ is rejected and $\mathrm{H}_{1}$ hypothesis is confirmed and this relationship is significant. Also based on this table will be said intensity of correlation between two variables television advertisement and increase attracting customers is 0.14 that this indicates a direct correlation between the two variables. Therefore, this hypothesis is confirmed.

Table2. Regression test between Television advertisement and increase attracting customers

\begin{tabular}{|c|c|c|c|c|c|}
\hline & $\mathrm{R}$ & $\mathrm{R}^{2}$ & B & Constant & Sig \\
\hline $\begin{array}{l}\text { Television } \\
\text { advertisement and } \\
\text { increase attracting } \\
\text { customers }\end{array}$ & 0.14 & 0.018 & 0.14 & 3.05 & 0.005 \\
\hline
\end{tabular}

According to the sig is less than 0.05 , relationship between two variables of television advertisement and increase attracting customers at $95 \%$ is a significant, intensity of relationship is $14 \%$. To determine direction of this effect according to coefficient of B is observed that this effect is direct and positive. On the other hand $\mathrm{R}^{2}$ in this hypothesis is 0.018 . This means that independent variable can predict $1.8 \%$ changes of dependent variable. So regression model can be written as follows: 


$$
\mathrm{Y}=0.14 \mathrm{X}+3 / 05
$$

On the other hand $\mathrm{R}^{2}$ is squared $\mathrm{R}$ that is moving in the range of zero to one and is called square of the correlation coefficient and is equal to ratio of regression squares to sum of total squares (residual) and in fact it is part of a variable changes that is dependent on other variable and is more meaningful factor than $\mathrm{R}$ that its amount is 0.0196 , this means that size of this amount can predict dependent variable changes.

\subsection{Second Sub-Hypothesis}

Radio advertisement increases attracting customers to use electronic services.

$\mathrm{H}_{0}$ : Radio advertisement doesn't increase attracting customers to use electronic services.

$\mathrm{H}_{1}$ : Radio advertisement increases attracting customers to use electronic services.

Table3. Correlation coefficient between radio advertisement and increase attracting customers

\begin{tabular}{|l|l|l|ll|l|}
\hline Variables & Number & Correlation coefficient & Sig & Result \\
\hline $\begin{array}{l}\text { Radio advertisement and } \\
\text { increase attracting customers }\end{array}$ & 384 & 0.12 & 0.009 & Confirmed \\
\hline
\end{tabular}

According to the table can be seen that sig $=0.009<0.05$, for this reason with $95 \%$ confidence $\mathrm{H}_{0}$ is rejected and $\mathrm{H}_{1}$ hypothesis is confirmed and this relationship is significant. Also based on this table will be said intensity of correlation between two variables radio advertisement and increase attracting customers is 0.12 that this indicates a direct correlation between the two variables. Therefore, this hypothesis is confirmed.

Table4. Regression test between Radio advertisement and increase attracting customers

\begin{tabular}{|c|c|c|c|c|c|}
\hline & $\mathrm{R}$ & $\mathrm{R}^{2}$ & B & Constant & Sig \\
\hline $\begin{array}{l}\text { Radio } \\
\text { advertisement and } \\
\text { increase attracting } \\
\text { customers }\end{array}$ & 0.12 & 0.012 & 0.12 & 3.9 & 0.01 \\
\hline
\end{tabular}

According to the sig is less than 0.05 , relationship between two variables of radio advertisement and increase attracting customers at $95 \%$ is a significant, intensity of relationship is $12 \%$. To determine direction of this effect according to coefficient of B is observed that this effect is direct and positive. On the other hand $\mathrm{R}^{2}$ in this hypothesis is 0.012 . This means that independent variable can predict $1.2 \%$ changes of dependent variable. So regression model can be written as follows:

$$
\mathrm{Y}=0.12 \mathrm{X}+3 / 9
$$

On the other hand $\mathrm{R}^{2}$ is squared $\mathrm{R}$ that is moving in the range of zero to one and is called square of the correlation coefficient and is equal to ratio of regression squares to sum of total squares (residual) and in fact it is part of a variable changes that is dependent on other variable and is more meaningful factor than $\mathrm{R}$ that its amount is 0.0144 , this means that size of this amount can predict dependent variable changes.

\subsection{Third Sub-Hypothesis}

Press advertisement increases attracting customers to use electronic services.

$\mathrm{H}_{0}$ : Press advertisement doesn't increase attracting customers to use electronic services.

$\mathrm{H}_{1}$ : Press advertisement increases attracting customers to use electronic services.

Table5. Correlation coefficient between Press advertisement and increase attracting customers

\begin{tabular}{|l|l|l|l|l|}
\hline Variables & Number & Correlation coefficient & Sig & Result \\
\hline $\begin{array}{l}\text { Press advertisement and } \\
\text { increase attracting customers }\end{array}$ & 384 & 0.05 & 0.15 & Rejected \\
\hline
\end{tabular}

According to the table can be seen that sig=0.15>0.05, for this reason with $95 \%$ confidence $\mathrm{H}_{1}$ is rejected and $\mathrm{H}_{0}$ hypothesis is confirmed and this relationship is not significant and do not confirm. So hypothesis is rejected. 
The Effect of Commercial Advertising on Customer Orientation in the Banking System (Case Study: The Branches of Mellat Bank in Guilan Province-North of Iran)

Table6. Regression test between Press advertisement and increase attracting customers

\begin{tabular}{|l|l|l|l|l|l|l|}
\hline & & $\mathrm{R}$ & $\mathrm{R}^{2}$ & $\mathrm{~B}$ & Constant & Sig \\
\hline $\begin{array}{l}\text { Press advertisement and } \\
\text { increase attracting customers }\end{array}$ & 0.05 & 0.003 & 0.05 & 3.3 & & 0.3 \\
\hline
\end{tabular}

According to the sig is higher than 0.05 , relationship between two variables of press advertisement and increase attracting customers at $95 \%$ is not a significant.

\subsection{Fourth Sub-Hypothesis}

Advertisement by catalogues and brochures increases attracting customers to use electronic services.

$\mathrm{H}_{0}$ : Advertisement by catalogues and brochures doesn't increase attracting customers to use electronic services.

$\mathrm{H}_{1}$ : Advertisement by catalogues and brochures increases attracting customers to use electronic services.

Table7. Correlation coefficient between advertisement by catalogues and brochures and increase attracting customers

\begin{tabular}{|l|l|l|l|l|}
\hline Variables & Number & Correlation coefficient & Sig & Result \\
\hline $\begin{array}{l}\text { Advertisement by catalogues and } \\
\text { brochures and increase attracting } \\
\text { customers }\end{array}$ & 384 & 0.085 & 0.05 & Rejected \\
\hline
\end{tabular}

According to the table can be seen that sig $=0.05=0.05$, for this reason with $95 \%$ confidence $\mathrm{H}_{1}$ is rejected and $\mathrm{H}_{0}$ hypothesis is confirmed and this relationship is not significant.

Table8. Regression test between advertising by brochures and increase attracting customers

\begin{tabular}{|l|r|r|rr|r|r|}
\hline & $\mathrm{R}$ & $\mathrm{R}^{2}$ & & $\mathrm{~B}$ & Constant & \multicolumn{1}{|c|}{ Sig } \\
\hline $\begin{array}{l}\text { Advertisement by catalogues and brochures } \\
\text { and increase attracting customers }\end{array}$ & 0.085 & 0.005 & 0.085 & 3.2 & 0.09 \\
\hline
\end{tabular}

According to the sig is higher than 0.05 , relationship between two variables of advertisement by catalogues and brochures and increase attracting customers at $95 \%$ is not a significant.

\subsection{Fifth Sub-Hypothesis}

5. Oral advertising by bank personal increases attracting customers to use electronic services.

$\mathrm{H}_{0:}$ Oral advertising by bank personal doesn't increase attracting customers to use electronic services.

$\mathrm{H}_{1}$ : Oral advertising by bank personal increases attracting customers to use electronic services.

Table9. Correlation coefficient between oral advertising by bank personal and increase attracting customers

\begin{tabular}{|c|c|c|c|c|}
\hline Variables & Number & Correlation coefficient & Sig & Result \\
\hline $\begin{array}{c}\text { Oral advertising by bank personal } \\
\text { and increase attracting customers }\end{array}$ & 383 & 0.16 & 0.000 & Confirmed \\
\hline
\end{tabular}

According to the table can be seen that sig $=0.000<0.05$, for this reason with $95 \%$ confidence $\mathrm{H}_{0}$ is rejected and $\mathrm{H}_{1}$ hypothesis is confirmed and this relationship is significant. Also based on this table will be said intensity of correlation between two variables oral advertising by bank personal and increase attracting customers is 0.16 that this indicates a positive correlation between the two variables. Therefore, this hypothesis is confirmed

Table10. Regression test between oral advertising by bank personal and increase attracting customers

\begin{tabular}{|c|c|c|c|c|c|}
\hline & $\mathrm{R}$ & $\mathrm{R}^{2}$ & $\mathrm{~B}$ & Constant & Sig \\
\hline $\begin{array}{c}\text { Oral advertising by bank personal } \\
\text { and increase attracting customers }\end{array}$ & 0.16 & 0.02 & 0.16 & 2.9 & 0.001 \\
\hline
\end{tabular}

According to the sig is less than 0.05 , relationship between two variables of oral advertising by bank personal and increase attracting customers at $95 \%$ is a significant, intensity of relationship is 0.16 . To determine direction of this effect according to coefficient of B is observed that this effect is direct and positive. On the other hand $\mathrm{R}^{2}$ in this hypothesis is 0.02 . This means that independent variable can predict $2 \%$ changes of dependent variable. So regression model can be written as follows: 
The Effect of Commercial Advertising on Customer Orientation in the Banking System (Case Study: The Branches of Mellat Bank in Guilan Province-North of Iran)

$$
\mathrm{Y}=0 / 16 \mathrm{X}+2 / 9
$$

On the other hand $\mathrm{R}^{2}$ is squared $\mathrm{R}$ that is moving in the range of zero to one and is called square of the correlation coefficient and is equal to ratio of regression squares to sum of total squares (residual) and in fact it is part of a variable changes that is dependent on other variable and is more meaningful factor than $\mathrm{R}$ that its amount is 0.256 , this means that size of this amount can predict dependent variable changes.

Table11. Ranking advertising elements

\begin{tabular}{|c|c|}
\hline Advertising elements & \\
\hline attention & 2.99 \\
\hline Stimulate & 3.26 \\
\hline interest & 3.56 \\
\hline Trust & 2.58 \\
\hline Movements & 2.61 \\
\hline
\end{tabular}

Chi-Square $=120.39 \quad$ d.f $=4 \quad$ sig $=0.000$

According to Table 12 shows that Sig <0/05, H1 is accepted, I.e. difference between variables (elements) is significant and advertising elements differ in size of influence on attracting customers and interest has most effect and trust has the least effect.

Table12. Ranking a variety of advertising items

\begin{tabular}{|c|c|}
\hline A variety of Advertising items & \\
\hline television & 3.30 \\
\hline Radio & 2.45 \\
\hline Press & 3.04 \\
\hline Brochure & 3.03 \\
\hline Oral advertisement & 3.19 \\
\hline
\end{tabular}

Chi-Square $=67.96$

d.f $=4 \quad$ sig $=0.000$

According to table 12 shows that $\mathrm{Sig}<0 / 05, \mathrm{H}_{1}$ is accepted, Ie difference between variables (elements) is significant and advertising items differ in size of influence on attracting customers and television has most effect and radio has the least effect.

\subsection{Main Hypothesis}

Advertising increases attracting customers to use electronic services.

$\mathrm{H}_{0}$ : Advertising doesn't increase attracting customers to use electronic services.

$\mathrm{H}_{1}$ : Advertising increases attracting customers for use of electronic services.

Table13. Regression test between advertisement and increase attracting customers

\begin{tabular}{|c|c|c|c|c|c|}
\hline & $\mathrm{R}$ & $\mathrm{R}^{2}$ & $\mathrm{~B}$ & Constant & model Sig \\
\hline $\begin{array}{c}\text { Advertisement and increase } \\
\text { attracting customers }\end{array}$ & 0.99 & 0.98 & 0.325 & 0.139 & $\begin{array}{c}0.000 \\
\text { Beta sig }=0.000\end{array}$ \\
\hline
\end{tabular}

According to the sig is less than 0.05 , relationship between two variables of advertisement and increase attracting customers at $95 \%$ is a significant, intensity of relationship is 0.99 and direction of this effect according to coefficient of $\mathrm{B}$ is direct and positive. On the other hand coefficient of determination in this hypothesis is 0.98 . This means that advertisement can predict $98 \%$ changes of attracting customers. So with 95 percent $\mathrm{H}_{0}$ is rejected and $\mathrm{H}_{1}$ is confirmed and this relationship is significant, and main hypothesis is confirmed.

On the other hand $\mathrm{R}^{2}$ is squared $\mathrm{R}$ that is moving in the range of zero to one and is called square of the correlation coefficient and is equal to ratio of regression squares to sum of total squares (residual) and in fact it is part of a variable changes that is dependent on other variable and is more meaningful factor than $\mathrm{R}$ that its amount is 0.9604 , this means that size of this amount can predict dependent variable changes.

\section{CONCLUSION AND RECOMMENDATIONS}

Nowadays, concerning the competitive atmosphere which governs the banks regarding e-services, using advertisement to introduce services has a significant role in inspiring and motivating customers 
in using products and services and consequently attracting them to use their e-services. In other words, if the banks wish to evaluate the efficiency of their advertisement on the customers, they can perform better in future which is a distinctive competence for the banks. In this regard, there have been various researches throughout the country which merely investigated the effective factors in advertising or the advertising facilities. The present study was conducted on the customers of the branches of Mellat Bank in Guilan province, aiming to answer whether advertisement has caused any improve in the customers' attraction to use the branches of Mellat Bank e-services, such as mobile banking, telephone banking, internet banking, shopping centers' POS (Point of Sale), and ATM (Automated Teller Machine), and if they are effective, the effect of which ones (television advertisement, radio advertisement, catalogues and brochures, press or oral advertising) are more considerable. The results of this study show that television advertising, radio, oral by the personnel of banks increased attracting customers for use of electronic services but impact of advertising through catalogs and brochures, the press was not confirmed. Also advertising elements differ in size of influence on attracting customers and interest has most effect and trust has the least effect. Advertising items differ in size of influence on attracting customers and television has most effect and radio has the least effect. Thus, according to results obtained following recommendations are offered:

It is recommended that banks according to the results of this study (the impact of advertising on consumer attract of electronic banking services) use in order to improve their performance and increase the benefit of banking resources.

It is recommended that banks in planning their advertising use from results of this study and impact of advertising tools and equipment to attract customers and as a result use from investment losses of advertising and thus reduce the cost of bank.

It is recommended that bank marketing departments to find new markets and attract customers consider the impact of advertising and promotional items.

\section{REFERENCES}

[1] Ademola B. Owolabi, Ph.D., (2019)."Effect of Consumers Mood on Advertising Effectiveness", Department of Psychology,University of Ado-Ekiti, Nigeria, Europe's Journal of Psychology 4/2009, pp. 118-127.

[2] Claudia M. Buch, Cathérine T. Koch c, Michael Koetter," (2019). Size, productivity, and international banking", Journal of International Economics,accepted 2011

[3] Gilaninia, Sh; Taleghani, M; Taheri, T; Mousavian, S .J. (2011). Study of effective factors on customers trust in electronic banking services (Case study: Melli Bank in Ardabill City), Interdisciplinary Journal of Contemporary Research in Business 3(8): 472-478.

[4] Gilaninia, S., Delafrooz, N., \& Machiani, A. R. N. (2018). Identifying Effective Factors on Consumer Intention to use Mobile Banking Services. Journal of Basic and Applied Scientific Research, 2(11), 1101411020.

[5] Parhizgar,M.M; Mahdipour,S.(2020). The effects of advertising on increasing knowledge of consumers in National Iranian Oil Company in the province ", PNU units of Damavand, Iran.

[6] Rabiei,A; Mohammadian, M; Baradaran Jamili,B.(2019). Evaluating the effectiveness of advertising in Persian Bank-Iran and identify the most important factor in increasing the effectiveness of it in Tehran, "the first year, the second issue, pp. $17-40$.

[7] Rasool F-Jalal. (2018). Strategies to improve and diversify the banking system (Case Study : Agricultural Bank) ", Proceedings papers of the Sixteenth Conference of Islamic banking, publishing the Central Bank of the Islamic Republic of Iran, Higher Institute of Banking Iran.

\section{AUTHORS' BIOGRAPHY}

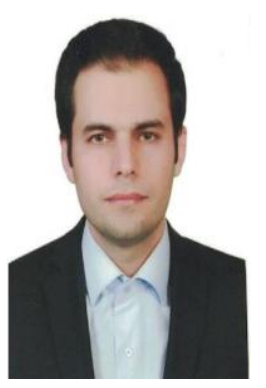

Seyed Javad Mousavian, is graduated MBA from Azad University of Iran and $\mathrm{PhD}$ candidate in Business Management. He is interested in Marketing, Strategic Marketing, and Consumer Behavior. 
The Effect of Commercial Advertising on Customer Orientation in the Banking System (Case Study: The Branches of Mellat Bank in Guilan Province-North of Iran)

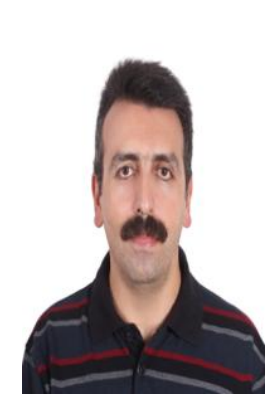

Mohammad Taleghani, Associate professor and full-time faculty members of Islamic Azad University of Rasht (Faculty of Management and Accounting, Department of postgraduate, MBA and government and industry educational groups) - From 1995 until now.

Citation: Seyed Javad Mousavian, Mohammad Taleghani. " The Effect of Commercial Advertising on Customer Orientation in the Banking System (Case Study: The Branches of Mellat Bank in Guilan ProvinceNorth of Iran)" International Journal of Humanities Social Sciences and Education (IJHSSE), vol 8, no. 2, 2021, pp. 236-243. doi: https://doi.org/10.20431/2349-0381.0802024.

Copyright: (C) 2021 Authors. This is an open-access article distributed under the terms of the Creative Commons Attribution License, which permits unrestricted use, distribution, and reproduction in any medium, provided the original author and source are credited. 